\title{
Yellow Tainting of Flesh in Pangasius (Pangasianodon hypophthalmus): Origin of the Color and Procedures for Removal
}

\author{
Seikh Razibul Islam ${ }^{1,2}$ (D), Mohammad Mahfujul Haque ${ }^{3}$ (D), Muhammad Abdur Razzak ${ }^{2}$ (D) Louise Schlüter ${ }^{4}$ (D), \\ Emranul Ahsan ${ }^{1,5}$ (D), Raju Podduturi' ${ }^{10}$, Niels O. G. Jørgensen ${ }^{1}$ (i)
}

Cite this article as: Islam, S.R., Haque, M.M., Razzak, M.A., Schlüter, L., Ahsan, E., Podduturi, R., \& Jørgensen, N.O.G. (2021). Yellow tainting of flesh in pangasius (Pangasianodon hypophthalmus): Origin of the color and procedures for removal. Aquatic Sciences and Engineering, 36(4), $193-201$.

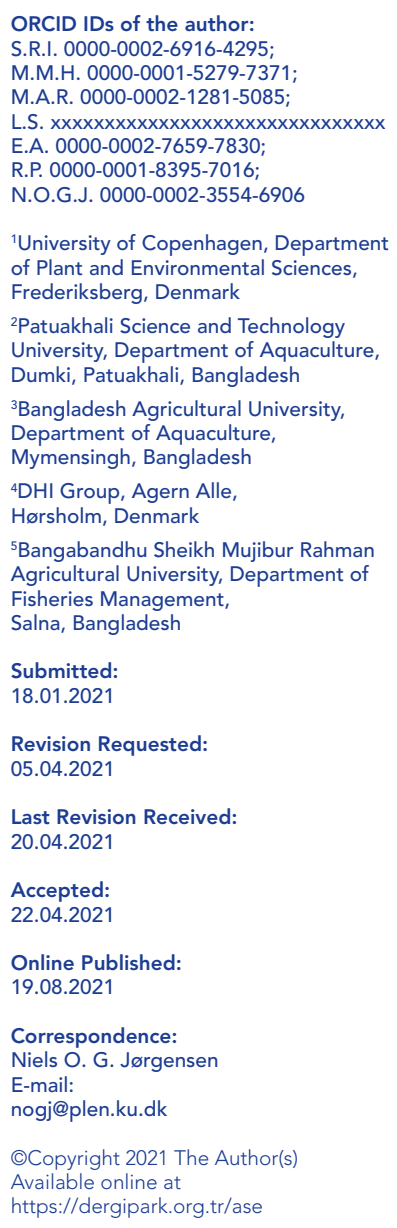

\begin{abstract}
Pangasius (Pangasianodon hypophthalmus) is a commonly farmed fish in ponds in Bangladesh but its yellow flesh color creates a barrier for export. Here, we investigated if feed ingredients and environmental parameters might impact yellow tainting of the flesh. In experimental feeds, maize (a typical ingredient in commercial feeds) was replaced by soybean meal, and frequent exchange of pond water was introduced. Chemical analyses showed that the commercial feed was high in carotenoids (lutein, zeaxanthin and $\beta$-carotene; $18.8 \mathrm{mg} / \mathrm{kg}$ ) as compared to the experimental feeds ( $\leq 1 \mathrm{mg}$ carotenoids $/ \mathrm{kg}$ ). After feeding the fish commercial and experimental feeds for 9 months, the content of total carotenoids in the flesh was reduced by $48 \%$ to $64 \%$ and visual yellowness by up to $47 \%$ by the experimental feeds. Weekly or biweekly water exchange in combination with the experimental feeds further reduced the yellow coloration to $22 \%$ relative to fish given commercial feed and without water exchange. Our study demonstrates that pangasius with white flesh can be produced in Bangladesh by combining feeds low in pigments with frequent water exchange.
\end{abstract}

Keywords: Pangasius, yellow flesh, water quality, feed composition, maize, carotenoids

\section{INTRODUCTION}

Catfish are globally widespread and are also commonly produced fish in subtropical and tropical aquaculture (FAO, 2018). In south and southeastern Asia, an important catfish species in freshwater fish farming is pangasius (Pangasianodon hypophthalmus) (Jespersen et al., 2014). In Bangladesh, pangasius was the most produced aquaculture species in 2017 and 2018 and reached a production of 453,383 tons (DoF, 2018). Export of pangasius from Bangladesh is currently limited and the fish are mainly sold at domestic markets (Alam et al., 2019). Recently, pangasius production has exceeded local demand and this has opened an option for export, but lack of interest by international companies in the import of pangasius has hindered the establishment of a profitable export-oriented pangasius industry in Bangladesh. A main barrier for the export appears to be the yellow flesh color that occurs in some catfish species (Qiufen et al., 2012) and that has been reported as a common characteristic of pangasius produced in Bangladesh, as illustrated in Figure 2A $\& B$ and reported by Hoque et al. (2021). On the basis that the yellow color limits the export of pangasius from Bangladesh, pangasius with white flesh but produced in other Asian countries, e.g., Vietnam, has successfully been exported to Europe and other international markets (Belton et al., 2011; FAO, 2019).

Consumers tend to prefer fish with white flesh (Lovell, 1998), except for species with a known different color, such as pinkish flesh in salmon (Sheehan et al., 1998). In some countries, especially in USA and Europe, consumers are often reluctant to buy fish products with yellow pigmentation, because they suspect the fillets are 
damaged, spoiled or have been stored longer than the "best before" date (Lovell, 1984; Shahidi et al., 1998).

The yellow color of catfish flesh is typically caused by the yellow-orange carotenoid pigments carotenes and their oxygenated derivatives xanthophylls (Lee, 1987; Li et al., 2007; Maoka et al., 1989). Different species of fish accumulate different kinds of carotenoids (de Carvalho \& Caramujo, 2017), but the xanthophylls lutein and zeaxanthin are considered the primary yellow pigments in catfish (Lee, 1987; Li et al., 2011). Carotenoids are synthesized by microorganisms and plants and are not produced by animals. Hence, carotenoids in catfish originate from an external source. In commercial production, carotenoids may either be feed ingredients or originate from ingestion of materials or organisms in the water. Common ingredients in catfish feeds are maize, corn gluten meal and mustard oil cake due to their protein content, but these plant products may also contribute to accumulation of carotenoids in fish flesh (Lee, 1987).

Catfish are omnivore, opportunistic fish that in their wild habitats feed on algae, aquatic plants, crustaceans, as well as on other organisms in the water (Zimba et al., 2003). This means that natural, carotenoid-containing organisms in water in fish farms may also contribute carotenoids in catfish flesh after ingestion. Supporting this, a correlation between xanthophylls in catfish and microorganisms $>75 \mu \mathrm{m}$ (assumed to be mainly phytoplankton) was observed by Hu et al. (2013). Some reports mention that environmental conditions, e.g., low oxygen content and a high ammonium level, can also cause yellow discoloration in pangasius (Qiufen et al., 2012; Waycott, 2015), but no scientific evidence was given in these reports.

The yellow pigments do not influence the flavor, taste, storage capacity, or safety of catfish flesh (Lovell, 1998), and there are indications that consumption of yellow pigments might be beneficial to human health (Snodderly, 1995; Young \& Lowe, 2001). However, unless consumer acceptance of yellowish color in catfish changes, yellow catfish fillets will still be opted out by most consumers.

The difference in flesh color of pangasius raised in Vietnam and Bangladesh is not related to species, since taxonomically identical pangasius species are cultured in both countries (Belton et al., 2011). Rather, fish farm practices with respect to feed ingredients, and possibly also water quality, might explain the yellowish color but so far, no experimental evidence for such effects has been given.

In this study, we fed pangasius different diets with a variable content of carotenoids and manipulated the water exchange in experimental ponds. To mimic actual conditions in commercial fish farms, earthen ponds with natural well water were used in the study. We hypothesize that changed feeds and possibly also better monitoring and control of the water quality can reduce the yellow color in pangasius flesh.

\section{MATERIAL AND METHODS}

\section{Field experiment setup}

A controlled field study was conducted for 9 months between May 2018 and January 2019 in uniformly sized soil fishponds, each with a surface area of $40.5 \mathrm{~m}^{2}$ and a depth of $1.20 \mathrm{~m}$, at the
Faculty of Fisheries, Bangladesh Agricultural University (BAU), Mymensingh, Bangladesh. Before the start of the experiments, all ponds were dried out in the sun to exclude the presence of other fish species in the ponds. Separate inlet and outlet canals were built into each pond to prevent the exchange of fish between ponds, and dikes prevented the entry of other fish and the escape of stocks. The pond soil was conditioned with lime as is practiced in Bangladesh to improve the structure of the pond soil. After two weeks, the ponds were filled with underground water up to $1 \mathrm{~m}$ in depth, and after an additional week, healthy and uniformly sized fingerlings (average length of $20 \mathrm{~cm}$ and weight of $60 \mathrm{~g}$ ) were stocked at a rate of $5 / \mathrm{m}^{2}$. The fish for analysis were harvested in September, October and January (see below). No mortality of fish was observed in any of the treatment.

\section{Feed formulation and feeding}

Based on the hypothesis that certain ingredients in standard pangasius feed cause the yellow coloration of fish flesh, two experimental feeds were formulated and fed to the fish. A commercial pangasius feed type (Pangasius floating feed; www.megafeedbd.com) served as the control. Ingredients in commercial pangasius feed (feed type 1; FT-1) typically include fish meal, meat and bone meal, maize, soybean meal, rice bran, mustard oil cake, wheat flour, salt, and vitamin and mineral premix. The proportion of maize and mustard oil cake in commercial feeds in Bangladesh usually varies from $10-25 \%$ and $10-15 \%$ (Ali et al., 2013), respectively. We suspected that these two ingredients were mainly responsible for the yellow color in pangasius flesh. Therefore, the two experimental feed types were formulated without maize and mustard oil cake, and each feed had a content of crude protein of $30 \%$. Feed type 2 (FT-2) contained fish meal (25\%), soybean meal (25\%), rice bran (24\%), wheat flour (24\%), salt (1\%), and vitamin-mineral premix (1\%). Feed type 3 (FT-3) was made from meat and bone meal as the main animal protein source $(30 \%)$, while soybean meal $(30 \%)$ was the main plantbased protein source. The remaining ingredients were rice bran (19\%), wheat flour (19\%), salt (1\%), and vitamin-mineral premix (1\%). The ingredients were finely ground, mixed with clean water and made into pressed pellets by a fish feed pelleting machine. The content of carotenoids varied from $18.8 \mathrm{mg} / \mathrm{kg}$ in the commercial feed to about $0.9 \mathrm{mg} / \mathrm{kg}$ in the experimental feeds (determined from published values) (Table 1). Individual proportions of the carotenoids lutein, zeaxanthin and $\beta$-carotene in the three feeds were 43, 56 and 1\% (commercial feed), 81, 8 and 11\% (experimental feed 2), and 83, 6 and $11 \%$ (experimental feed 3), respectively. The fish were fed the three feed types as $3.0-4.0 \mathrm{~mm}$ pellets at a rate of $4-5 \%$ of their average body weight twice a day and this was adjusted bi-weekly with the body weight.

\section{Management of ponds, feeds and water exchange}

Instead of small replicate ponds with few fish, single but large ponds with many fish (200 fish per pond) were used for each treatment. Pond 1 was the control pond and the fish were fed the commercial feed (FT-1) and no water exchange (NWEX) was applied. Fish in Pond 2, 3 and 4 received our own formulated feed type 2 (FT-2) and had no, 50\% fortnightly, or 50\% weekly water exchange (NWEX, FWEX or WWEX, respectively). Fish in Pond 5, 6 and 7 received our own formulated feed type 3 (FT-3) and had 
Table 1. Different feed types and their composition.

\begin{tabular}{|c|c|c|c|}
\hline \multirow{2}{*}{ Ingredients } & \multicolumn{3}{|c|}{$\begin{array}{l}\text { Percentage dry weight (except for } \\
\text { carotenoids) }\end{array}$} \\
\hline & $\begin{array}{l}\text { Feed type } \\
1 \text { (FT-1) }\end{array}$ & $\begin{array}{l}\text { Feed type } \\
2 \text { (FT-2) }\end{array}$ & $\begin{array}{l}\text { Feed type } \\
3 \text { (FT-3) }\end{array}$ \\
\hline Fish meal & 10 & 25 & - \\
\hline $\begin{array}{l}\text { Meat and bone } \\
\text { meal }\end{array}$ & 13 & - & 30 \\
\hline Maize & 11 & - & - \\
\hline Soybean Meal & 6 & 25 & 30 \\
\hline Rice bran & 38 & 24 & 19 \\
\hline Mustard oil cake & 10 & - & - \\
\hline Wheat flour & 8 & 24 & 19 \\
\hline Salt & 1 & 1 & 1 \\
\hline $\begin{array}{l}\text { Vitamin-mineral } \\
\text { premix }\end{array}$ & 1 & 1 & 1 \\
\hline $\begin{array}{l}\text { Total carotenoids* } \\
(\mathrm{mg} / \mathrm{kg})\end{array}$ & 18.8 & 0.86 & 0.91 \\
\hline \multicolumn{4}{|c|}{$\begin{array}{l}\text { *Lutein, zeaxanthin and } \beta \text {-carotene. Content of carotenoids in the ingredients } \\
\text { was based on data by Aruna \& Baskaran (2010); Kim et al. (2010); Wu et al. } \\
\text { (2016); Trono (2019). }\end{array}$} \\
\hline
\end{tabular}

no, $50 \%$ fortnightly, or 50\% weekly water exchange (NWEX, FWEX or WWEX, respectively). For the commercial feed FT-1, no water exchange was applied to resemble real pond farming practices in which no water exchange is applied. Moreover, due to a limited availability of ponds for the study, we could not replicate different water exchange conditions for feed FT-1.

Comparisons of feed effects were done at identical water exchange conditions and with similar feeds at different water exchange conditions. Biological replicates of the fish (i.e., "parallel measurements of biologically distinct samples that capture random variation"; Blainey et al., 2014) were included in all observations to validate statistical analyses. The similar growth rates observed for fish in the different ponds, irrespective of feed type and water exchange, justify application of the large-pond strategy, relative to replicate and smaller ponds.

\section{Analysis of water quality and sampling of fish}

Water quality parameters were measured monthly from May to October in 2018, and in January 2019. On each sampling day, temperature, dissolved oxygen and $\mathrm{pH}$ were measured between 9:00 and 11:00 using portable devices (www.extech.com) at the sampling site, while water transparency was measured with a Secchi disk. Ammonia, nitrate and ortho-phosphate were measured immediately after return to the laboratory by application of specific reagent kits by Lovibond (www.lovibond.com). The fish were sampled at three time points (September, October and January) using nets. The fish were stunned and bled out by cutting of the gill blood vessels. Fillets of the fish were stored at $-70^{\circ} \mathrm{C}$ until analysis.

\section{Color analyses}

The color of the fish fillets was measured using the Commission Internationale de l'Eclairage (CIE) color system by measurement of $L^{*}, a^{*}, b^{*}$ values which are widely used to determine the color in- tensity of fish (Gouveia et al., 2003; Wathne et al., 1998). L* measures the lightness on a 100 - point scale, $+a^{*}$ measures the redness and $-a^{*}$ the greenness, $+b^{*}$ measures the yellowness and $-b^{*}$ the blueness. The $L^{*}, a^{*}, b^{*}$ values were measured with a Minolta CR-400 Chroma Meter (Konica Minolta, Inc., USA) using a pulsed xenon lamp with an $8 \mathrm{~mm}$ diameter opening, corresponding to the measuring surface. Before analysis, the instrument was calibrated with a white ceramic plate. To ensure a uniform analysis of the entire fillet, three measuring points were defined on the surface of the flesh side of the raw fillets (Figure 2C) (Li et al., 2011). All measurements were made on the flesh side of the fillets, since it appeared more homogeneous than the skin side, and at the same locations in each fillet. The results are expressed as mean value of readings from three points from the same fillet. After the measurements, the fillets were immediately stored in aluminum foil at $-70^{\circ} \mathrm{C}$ for subsequent carotenoid analysis by HPLC.

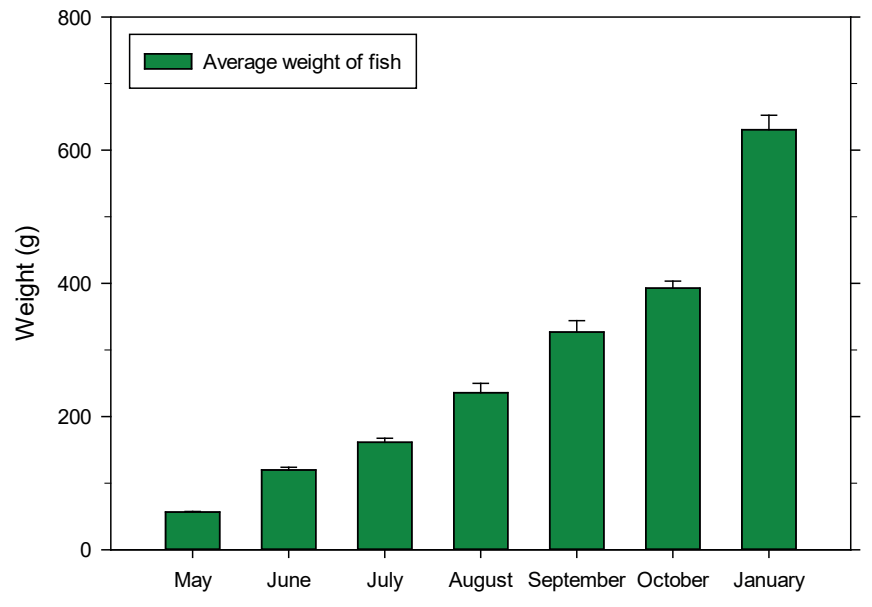

Figure 1. Weight of fish at the monthly samplings. The monthly weights were similar irrespective of feed and water exchange $(p>0.05 ; n=35$ fish at each sampling time; SEM shown).

\section{Extraction of pigments}

The procedure for extraction of carotenoids was modified from the technique given by Liu et al. (2012). Samples of fish fillet of $20 \mathrm{~g}$ were freeze-dried and ground in a mortar before addition of $20 \mathrm{ml}$ acetone. The acetone was mixed with the sample to dissolve the pigments before filtration through a glass fiber filter and transfer to a separating funnel. Four $\mathrm{ml} \mathrm{n}$-hexane and $20 \mathrm{ml}$ water were added to the acetone extract and mixed and left undisturbed for $15 \mathrm{~min}$ for separation to occur. Next, acetone and water were discarded, and the pigment extract was washed twice with Milli-Q water. The n-hexane layer was collected and filtered through Whatman $0.45 \mu \mathrm{m}$ nylon GMF filter paper before storage at $4^{\circ} \mathrm{C}$ in dark $2 \mathrm{ml}$ glass vials without headspace. Feed and feed ingredients were treated similarly by extraction of $5 \mathrm{~g}$ samples. Finally, all pigment extracts were concentrated by evaporation of $\mathrm{n}$-hexane under $\mathrm{N}_{2}$ stream and stored at $-20^{\circ} \mathrm{C}$ until subsequent HPLC analysis. 


\section{HPLC analysis of carotenoids}

Pigments were dissolved by addition of $6 \mathrm{ml} 95 \%$ acetone to each sample before sonication in an ice-cool sonication bath for $10 \mathrm{~min}$. To improve the solution of the pigments, the samples were left for $20 \mathrm{~h}$ at $4^{\circ} \mathrm{C}$, after which the extracts were vortex-mixed for $10 \mathrm{sec}$. In a few samples, a thin layer of whitish fat occurred at the bottom, but this layer was not included in the pigment analysis. Analysis of the carotenoids was carried out according to Schlüter et al. (2016) using the Van Heukelem and Thomas HPLC method (Van Heukelem and Thomas, 2001) with an adjusted pump gradient to optimize the resolution. The HPLC system consisted of a Shimadzu LC-10ADVP system with one pump (LC-10ADVP), photodiode array detector (SPD-M10AVP), SCL-10ADVP system controller with Lab Solution software, temperature-controlled auto sampler (SIL-10ADVP) (set at $4^{\circ} \mathrm{C}$ ), column oven (CTO-10ASVP), and degasser (ERC 3415a). Retention times of peaks were confirmed using pigment standards from DHI Lab Products, and peak identities were routinely confirmed by online photodiode array analysis. To further assure correct pigments concentrations in the fish flesh, replicates of five fish samples were validated and confirmed by a commercial laboratory (www.eurofins.dk).

\section{Statistics}

All statistical analyses were performed with the statistical software SPSS (version 23.0, SPSS, Chicago, IL, USA). Univariate analysis of variance (ANOVA) was performed through the General Linear Model (GLM) procedure in SPSS. The GLM procedure provides univariate ANOVA for one dependent variable by one or more independent variables. In the GLM, feed type and water exchange rate were included as independent variables to test for individual and interactive effects on several dependent variables, e.g., b*, zeaxanthin, lutein, etc. Tukey's test was applied for post hoc detection of significant pair-wise comparisons.

\section{RESULTS AND DISCUSSION}

\section{Physicochemical parameters and growth performance}

Seasonal water quality parameters in ponds receiving different feeds and with different water exchange rates are presented in Table 2. The water temperature ranged from $19.3^{\circ} \mathrm{C}$ in January to a maximum of $35.7^{\circ} \mathrm{C}$ in August. Relative to the commercial feed
FT-1, the experimental feeds FT-2 and FT-3 led to a higher oxygen content, lower concentrations of phosphate and ammonia (only in FT-3) and raised $\mathrm{pH}$ (ANOVA test). When weekly or biweekly water exchanges were applied, oxygen level (in FT-3 only) and water transparency increased, while phosphate was reduced (in FT-3 only) (ANOVA). The water exchange had variable effects on $\mathrm{pH}$, ammonia and nitrate.

Conditions for pangasius production in the ponds were representative for fish farms in Bangladesh with respect to temperature, oxygen level and inorganic nutrients (Abedin et al., 2017). However, in some periods the oxygen concentration was below the recommended level of $5 \mathrm{mg} \mathrm{O} / \mathrm{L}$ (Abedin et al., 2017; Ali et al., 2013), except in the ponds given feed FT-3 and with weekly or biweekly water exchange. It has been suggested that a low oxygen content and increased ammonium concentrations can lead to yellow coloration in pangasius (Qiufen et al., 2012; Waycott, 2015), but no studies have confirmed this. Many Bangladeshi fish farmers also assume that a reduced water quality is the main reason for the yellow flesh (own personal communication). Possibly, a relation between oxygen level, metabolic activity and yellow coloration might exist, as discussed below.

During the 9 months growth period, the biomass of fish from the different treatments increased from a mean weight of $57 \mathrm{~g}$ in May 2018 , to a mean weight of $631 \mathrm{~g}$ in January 2019. Weight gains at the monthly samplings were similar irrespective of feed and water exchange ( $p>0.05$; Figure 1).

\section{Color of fish flesh and effects of water exchange}

Feed type and water exchange affected the yellow coloration $b^{*}$ and the lightness $L^{*}$, but no changes of redness $a^{*}$ of the fish fillets were observed (Table 3). Lightness and yellowness correlated negatively, meaning that less yellow color occurred when the fillets had a higher lightness.

Without water exchange, the average yellowness $b^{*}$ at three sampling times (September, October and January) was 24.7 (feed FT-1), 19.7 (feed FT-2) and 15.7 (feed FT-3) (the $b^{*}$ values were statistically different; $p<0.05$ ) (Figure 3 ). Thus, a significant color improvement occurred when the fish were given the

Table 2. Water quality parameters in ponds with different feeds and water exchange rates. No water exchange (NWEX), $50 \%$ fortnightly water exchange (FWEX) or $50 \%$ weekly water exchange (WWEX) were applied.

\begin{tabular}{|c|c|c|c|c|c|c|c|c|}
\hline Feed & $\begin{array}{l}\text { Water } \\
\text { exchange } \\
\text { rates }\end{array}$ & $\begin{array}{c}\text { Temperature } \\
\left({ }^{\circ} \mathrm{C}\right) \\
(\min -\max )\end{array}$ & $\begin{array}{c}\text { Dissolved } \\
\text { oxygen (mg/l) }\end{array}$ & $\mathrm{pH}$ & $\begin{array}{l}\text { Transparen- } \\
\text { cy }(\mathrm{cm})\end{array}$ & $\begin{array}{c}\text { Ammonia } \\
(\mathrm{mg} / \mathrm{l})\end{array}$ & $\begin{array}{l}\text { Nitrate } \\
(\mathrm{mg} / \mathrm{l})\end{array}$ & $\begin{array}{c}\text { Phosphate } \\
\text { (mg/l) }\end{array}$ \\
\hline \multirow[t]{2}{*}{ FT-1 } & NWEX & $22.6-33.7$ & $5.15^{b} \pm 0.82$ & $6.66^{a} \pm 0.41$ & $15.74 \pm 5.10$ & $0.38^{\mathrm{ab}} \pm 0.32$ & $6.74 \pm 2.6$ & $1.50^{b} \pm 0.38$ \\
\hline & NWEX & $21.5-33.4$ & $4.53^{\mathrm{a}} \pm 0.86$ & $7.43^{b} \pm 0.53$ & $16.77^{x} \pm 4.93$ & $0.54^{b, y} \pm 0.56$ & $9.27 \pm 4.37$ & $0.26^{a, x} \pm 0.11$ \\
\hline \multirow[t]{3}{*}{ FT-2 } & FWEX & $19.3-35.7$ & $4.83 \pm 0.87$ & $7.02 \pm 0.67$ & $21.25^{y} \pm 3.06$ & $0.16^{x} \pm 0.18$ & $8.37 \pm 2.26$ & $0.24^{x} \pm 0.19$ \\
\hline & WWEX & $20.7-34.0$ & $4.70 \pm 0.79$ & $7.35 \pm 0.53$ & $27.89^{z} \pm 3.19$ & $0.44^{x y} \pm 0.55$ & $8.69 \pm 3.39$ & $0.39^{y} \pm 0.24$ \\
\hline & NWEX & $22.0-33.2$ & $5.78^{c, x} \pm 0.90$ & $7.38^{b} \pm 0.65$ & $15.89^{x} \pm 4.15$ & $0.14^{a} \pm 0.09$ & $8.37^{x} \pm 2.06$ & $1.29^{b, y} \pm 0.30$ \\
\hline \multirow[t]{2}{*}{ FT-3 } & FWEX & $23.4-34.3$ & $6.01^{x} \pm 0.65$ & $7.43 \pm 0.62$ & $21.49^{y} \pm 5.12$ & $0.19 \pm 0.10$ & $11.72^{y} \pm 4.60$ & $0.70^{x} \pm 0.34$ \\
\hline & WWEX & $22.7-35.4$ & $6.85^{y} \pm 0.76$ & $7.67 \pm 0.49$ & $28.36^{z} \pm 2.36$ & $0.11 \pm 0.06$ & $7.73^{x} \pm 1.60$ & $0.78^{x} \pm 0.45$ \\
\hline
\end{tabular}

*Different superscripts $(a, b, c)$ in the same column signify statistical differences in different feed types with no water exchange (NWEX) ( $p<0.05)$; superscripts $x, y, z$ in the same column signify statistical differences for application of fortnightly water exchange (FWEX) and weekly water exchange (WWEX) for feed type 2 (FT-2) and feed type $3(F T-3)(p<0.05)$. Means \pm 1 STD $(n=5)$ shown 
low-pigmented feeds FT-2 and FT-3, relative to the high-pigmented commercial feed FT-1.

With water exchange, the effects of the two low-pigmented feeds were significantly enhanced and caused an additional reduction in the yellow color of the fillets (Figure 3). The lowest observed yellowness ( $b^{*}$ - value 4.69) was observed in January in fish given feed type FT-3 and with a weekly water exchange (WWEX).

\section{Carotenoids in fish relative to carotenoids in feeds}

The absence of maize and mustard oil cake in the experimental feed types was clearly reflected in the pigment content of the fish flesh. Fish which had been fed the commercial feed accumulated more zeaxanthin $(187 \mathrm{ng} / \mathrm{g})$ and lutein $(213 \mathrm{ng} / \mathrm{g})$ than fish which had been fed the experimental feeds (zeaxanthin and lutein content with FT-2 and FT-3 was 96 and $71 \mathrm{ng} / \mathrm{g}$, and 128 and $67 \mathrm{ng} / \mathrm{g}$, respectively) (Table 4). $\beta$-carotene contributed only a little to the pigment concentrations (content of 2-5 ng/g). Two un-

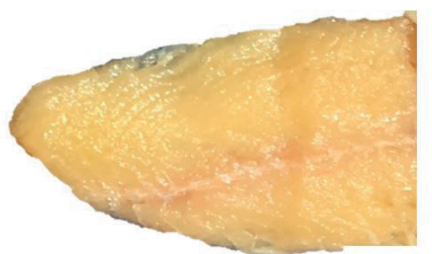

(A)

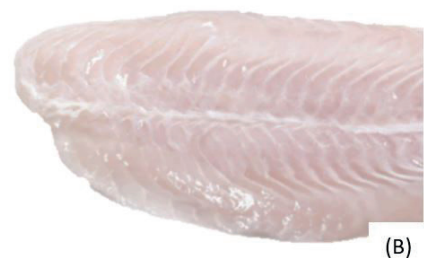

(B)

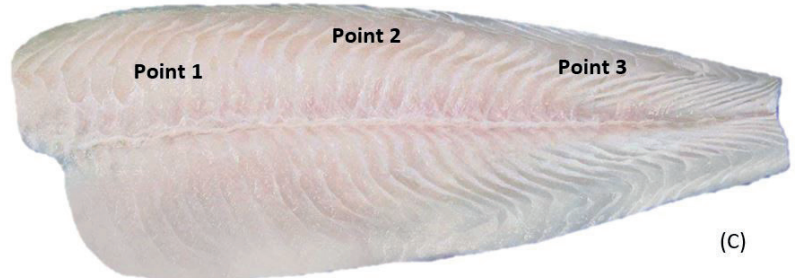

Figure 2. Intense yellow (A) and white (B) pangasius fillets from the studied ponds, and locations on pangasius fillet along the dorsal line (C) where the $L^{*}, a^{*}$ and $b^{*}$ - values were measured. identified pigments in the flesh with absorption maxima a few $\mathrm{nm}$ from zeaxanthin and lutein, and with retention time close to these two pigments in the HPLC chromatograms, were considered as derivatives of lutein and zeaxanthin and added to the total carotenoid content in Table 4. The sum of the carotenoids confirmed that the experimental feeds FT-2 and FT-3 led to a significantly lower content of carotenoids than feed FT-1 (summarized in Figure 5).

The co-occurrence of carotenoids in feed and fish shows that pigments in feed can be a main source for the coloring of flesh in catfish, as also observed for other catfish species (Qiufen et al., 2012). Supporting this relation, removal of carotenoids from the feed was found to reduce carotenoid pigments in fish. Li et al. (2011) fed catfish (Ictalurus punctatus) a diet containing zeaxanthin and lutein (total of $82 \mathrm{mg} / \mathrm{kg}$ feed) for 11

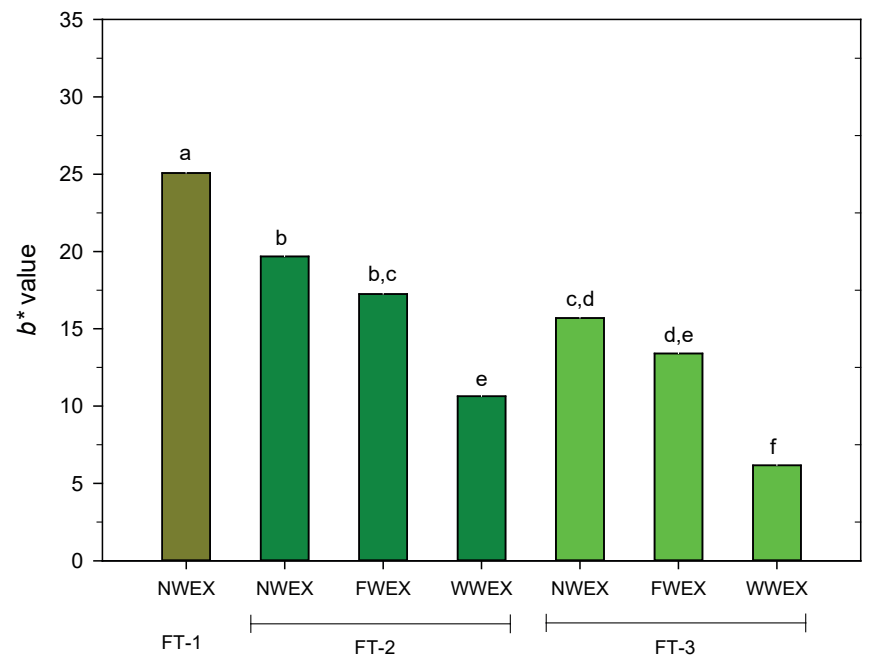

Figure 3. Visual yellow color of fillet (b*) in different feeds (FT$1, \mathrm{FT}-2$ and $\mathrm{FT}-3$ ) and water exchange rates (none (NWEX), fortnightly (FWEX) or weekly (WWEX) water exchange). Means of 15 fish shown. Letters above columns indicate significant differences $(p<0.05)$.

Table 3. Effects of different feeds and water exchange rates on $L^{*}$ (Lightness), $a^{*}$ (Redness) and $b^{*}$ (Yellowness) of fish fillets from three months. NWEX, FWEX and WWEX refer to none, fortnightly or weekly water exchange.

\begin{tabular}{|c|c|c|c|c|c|c|c|c|c|c|}
\hline \multirow[t]{2}{*}{ Feed } & \multirow{2}{*}{$\begin{array}{l}\text { Treat- } \\
\text { ment }\end{array}$} & \multicolumn{3}{|c|}{ September } & \multicolumn{3}{|c|}{ October } & \multicolumn{3}{|c|}{ January } \\
\hline & & $L^{*}$ & $a *$ & $b^{*}$ & $L^{*}$ & $a^{*}$ & $b^{*}$ & $L^{*}$ & $a^{*}$ & $b^{*}$ \\
\hline \multirow[t]{2}{*}{ FT-1 } & NWEX & $61.78^{\mathrm{a}, 1} \pm 1.75$ & $5.91 \pm 0.63$ & $26.42^{b} \pm 2.65$ & $64.52^{a, 12} \pm 2.27$ & $5.84 \pm 0.30$ & $26.30^{b} \pm 6.35$ & $66.44^{2} \pm 3.62$ & $5.91 \pm 0.16$ & $21.48^{b} \pm 5.41$ \\
\hline & NWEX & $62.31^{\mathrm{a}, 1} \pm 2.77$ & $6.65 \pm 0.92$ & $19.34^{a, y} \pm 2.51$ & $66.51^{\mathrm{a}, 2} \pm 1.37$ & $6.01 \pm 1.21$ & $19.32^{\mathrm{ab}, y} \pm 2.68$ & $68.26^{x, 2} \pm 2.61$ & $5.64 \pm 0.57$ & $20.38^{b, y} \pm 3.92$ \\
\hline \multirow{2}{*}{ FT-2 } & WWEX & $66.70^{1} \pm 1.97$ & $5.50 \pm 1.10$ & $10.85^{x} \pm 2.15$ & $70.06^{2} \pm 2.30$ & $6.61 \pm 0.50$ & $11.68^{x} \pm 5.07$ & $72.35^{y, 2} \pm 2.24$ & $6.23 \pm 0.75$ & $9.36^{x} \pm 3.60$ \\
\hline & NWEX & $71.10^{b} \pm 3.27$ & $5.82 \pm 1.48$ & $17.42^{\mathrm{a}, \mathrm{y}} \pm 1.82$ & $71.79^{b} \pm 2.15$ & $5.87 \pm 1.14$ & $17.38^{\mathrm{a}, \mathrm{y}} \pm 4.47$ & $70.86^{x} \pm 3.28$ & $5.22 \pm 0.39$ & $12.30^{\mathrm{a}, \mathrm{y}} \pm 3.20$ \\
\hline FT-3 & FWEX & $72.12 \pm 3.92$ & $6.08 \pm 0.77$ & $14.42^{y} \pm 2.80$ & $72.41 \pm 2.04$ & $6.11 \pm 0.48$ & $13.47^{y} \pm 2.95$ & $73.92^{x} \pm 3.32$ & $5.91 \pm 0.44$ & $12.33^{y} \pm 1.88$ \\
\hline
\end{tabular}

*Different superscripts $(a, b)$ in the same column signify statistical differences in different feed types at NWEX condition $(p<0.05)$; superscripts $x, y$ in the same column signify statistical differences in different water exchange conditions for feed type FT-2 and FT-3 ( $p<0.05)$; superscripts 1,2 in the same row signify statistical differences between different months $(p<0.05)$. Means \pm 1 STD $(n=5)$ shown. 
Table 4. Pigment profile of fish that were fed with different feed types and without water exchange. Fish were harvested in January 2019.

\begin{tabular}{lcccccc} 
Feed type & $\begin{array}{c}\text { Zeaxanthin } \\
(\mathbf{n g} / \mathbf{g})\end{array}$ & $\begin{array}{c}\text { Lutein } \\
(\mathbf{n g} / \mathbf{g})\end{array}$ & $\begin{array}{c}\beta \text {-carotene } \\
(\mathbf{n g} / \mathbf{g})\end{array}$ & $\begin{array}{c}\text { Unknown I } \\
(\mathbf{n g} / \mathbf{g})\end{array}$ & $\begin{array}{c}\text { Unknown II } \\
(\mathbf{n g} / \mathbf{g})\end{array}$ & $\begin{array}{c}\text { Total carotenoids } \\
(\mathbf{n g} / \mathbf{g})\end{array}$ \\
\hline FT-1 & $187^{\mathrm{b}} \pm 82$ & $213^{\mathrm{c}} \pm 80$ & $5^{\mathrm{a}} \pm 6$ & $37^{\mathrm{b}} \pm 15$ & $104^{\mathrm{b}} \pm 44$ & $546^{\mathrm{b}} \pm 212$ \\
FT-2 & $96^{\mathrm{a}} \pm 28$ & $18^{\mathrm{b}} \pm 38$ & $3^{\mathrm{a}} \pm 3$ & $20^{\mathrm{a}} \pm 8$ & $40^{\mathrm{a}} \pm 22$ & $287^{ \pm} \pm 87$ \\
FT-3 & $71^{\mathrm{a}} \pm 56$ & $67^{\mathrm{a}} \pm 47$ & $2^{\mathrm{a}} \pm 1$ & $19^{\mathrm{a}} \pm 9$ & $39^{\mathrm{a}} \pm 22$ & $197^{\mathrm{a}} \pm 130$ \\
\hline
\end{tabular}

*Different superscripts in the same column signify statistical differences $(p<0.05)$. Means \pm 1 STD $(n=10)$ shown

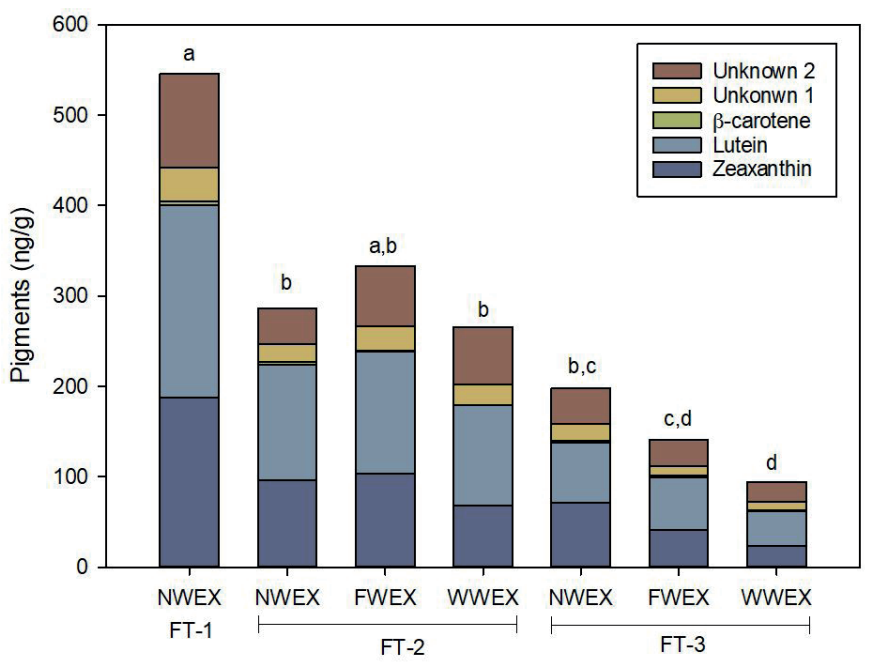

Figure 4. Carotenoids in fish fillet in different feeds (FT-1, FT-2 and FT-3) and water exchange rates (none (NWEX), fortnightly (FWEX) or weekly (WWEX) water exchange). Means of 10 fish shown. Letters above columns indicate significant differences $(p<0.05)$

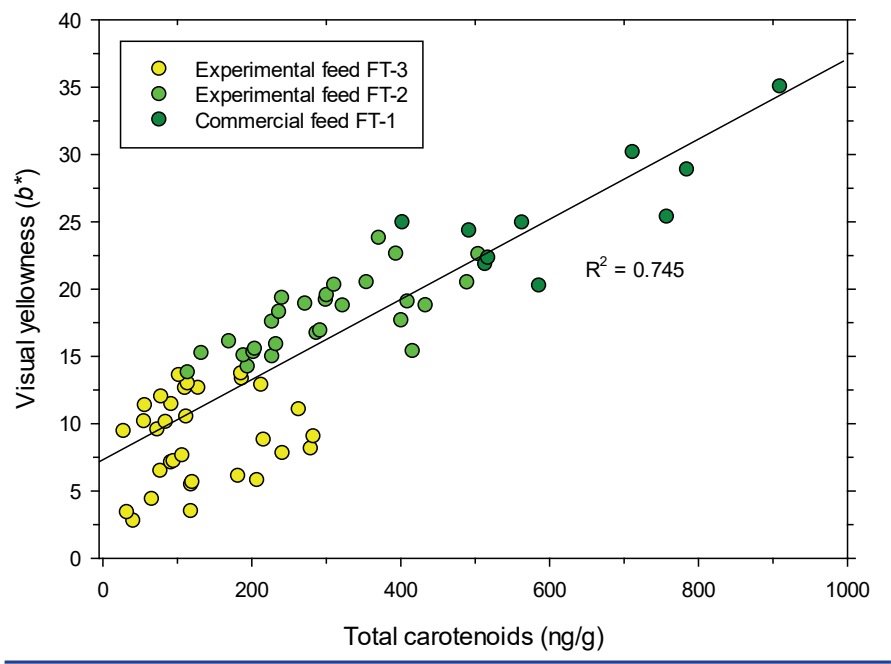

Figure 5. Relationships between visual yellow color $\left(b^{*}\right)$ and total carotenoids content $(\mathrm{ng} / \mathrm{g})$ in 70 fish. weeks, followed by 12 weeks without carotenoids in the feed, and this reduced carotenoids in the flesh from $12 \mu \mathrm{g} / \mathrm{g}$ to below $2 \mu \mathrm{g} / \mathrm{g}$ at $20^{\circ} \mathrm{C}$ or $30^{\circ} \mathrm{C}$ water temperature, while a lower reduction occurred at $10^{\circ} \mathrm{C}$. The temperature effect suggests that metabolic activity of the fish promoted the release of carotenoids.

Our study indicates that the replacement of a commercial feed, containing maize and mustard oil cake, with the experimental feeds without these two ingredients, can significantly reduce the total carotenoid content and cause a lower pigment content in the flesh and a decreased yellow flesh color. Maize is often used in commercial fish feeds to reduce costs, but maize is known to introduce a general risk of yellow tainting of fish flesh (Amaya \& Nickell, 2015). This was confirmed in breeding of tilapia in Chinese fish farms when using feeds rich in maize (Qiufen et al., 2012). Maize is an inexpensive ingredient that typically is mixed with mustard oil cake, fish meal, and meat and bone meal as the main ingredients in Bangladeshi fish feeds (Ali et al., 2013).

In contrast to Bangladeshi farms, maize is not used in pangasius production in Vietnam and here farm-produced pangasius is known for its white flesh color (Phan et al., 2009). In Vietnam, pangasius feed may include trash fish (usually of marine origin), fish meal powder, crushed dried fish, soybean meal, broken rice, and rice bran as the main ingredients in farm-made feed (Phan et al., 2009). The absence of maize in Vietnamese feeds and the white flesh color strongly suggest that maize is the main source of yellow tainting of pangasius flesh in Bangladesh due to the content of carotenoids, as suggested by Uddin et al. (2019). In general, it is not recommended to use feeds rich in carotenoids for catfish species, e.g., channel catfish, pangasius and African catfish, because these fish are expected to have white flesh (Amaya \& Nickell, 2015).

\section{Carotenoids in fish relative to water exchange}

Water exchange also affected the carotenoid content of the pangasius fish, but a significant effect was only found for FT-3. For FT2 , the weekly and biweekly water exchange did not affect the pigment content relative to the absence of water exchange (Figure 4). When the fish were fed FT-3, the total pigment content declined in proportion to the water exchange rate, reducing the content of carotenoids in the fish from $197 \mathrm{ng} / \mathrm{g}$ (no water exchange) to 94 $\mathrm{ng} / \mathrm{g}$ (weekly water exchange). Although not statistically significant, the biweekly water exchange also suggested that this reduced the carotenoid content in the fish (content of $140 \mathrm{ng} / \mathrm{g}$ ).

The frequent water exchange led to a higher oxygen content in the water, relative to absence of water exchange (Table 2). We speculate if the higher oxygen level stimulated physical activity 
and metabolic activity of the fish, causing a lower fat content. We did not determine the fat content of the fish, but visual inspection after slaughter showed a high accumulation of belly fat in fish which had been fed the commercial feed, as compared to fish given the experimental feeds. An increased fat content in fish given the commercial feed might also explain the higher content of carotenoid in these fish, since carotenoids are lipid soluble.

An alternative process that may have reduced the carotenoid content of the fish is a reaction with free radicals in the pond water. In waters with a high oxygen content, the level of free oxygen radicals in fish is typically also increased (Lushchak \& Bagnyukova, 2006). When carotenoids react with free radicals, the pigments lose color and pigment function (Qiufen et al., 2012). In our study, when fish were fed feed FT-3 and had weekly water exchange, the highest oxygen level occurred in the ponds and coincided with the lowest content of pigments in the fish. However, more analyses are required to determine whether free oxygen radicals can cause reduction of carotenoids in pangasius.

\section{Pigment composition of fish}

Surprisingly, the proportion of the different carotenoids in the fish did not differ between feeds nor relative to the water exchange. In the analyzed fish (total of 70 fish), the proportion of zeaxanthin, lutein, $\beta$-carotene, unknown 1 and unknown 2 was on average $30.7 \%, 40.3 \%, 0.6 \%, 8.3 \%$ and $20.2 \%$, respectively (Figure 4). No statistically significant differences from feed or water treatment on the composition were found. One noticeable observation, although not statistically significant, was reduction of zeaxanthin from $34 \%$ in fish fed FT-1 and without water exchange, to $25 \%$ in fish fed FT-3 with weekly water exchange.

The rather parallel variations of the five pigments suggest that changes in the matrix containing the pigments caused the different pigment contents. A changed pigment content might reflect metabolic conversion of individual pigments, as shown for astaxanthin and lutein, both of which can be converted to vitamin A in some catfish (Lee, 1987). A co-occurring removal of pigments (lutein and zeaxanthin) was also observed in catfish by Li et al. (2011) and supports that matrix containing the pigments, rather than the individual pigments, is reduced when fish lose pigments. In our study, the main matrix for the pigments was probably lipids in muscle tissues, but gonads and skin may also contain carotenoids (de Carvalho \& Caramujo, 2017).

\section{Visual yellow color vs. carotenoid content in fish}

When relating the measured $b^{*}$ values (indicating intensity of the yellow color) to the measured carotenoid concentrations, a strong relationship was found $\left(R^{2}=0.745\right)$ (Figure 5). Thus, higher carotenoid pigment concentrations coincided with a more intense yellow color. Similar relationships between the individual carotenoids and $b^{*}$ values had a weaker relationship (data not shown), suggesting that the sum of the major carotenoids gave the most precise indication of the yellow color.

In our study, temperature may also have affected the yellow color by influencing the amount of feed ingested by the fish. The lowest feeding rate occurred in the coldest month January (visual inspection showed that the fish were reluctant to eat the feed) and this probably explains the reduced yellow color observed for FT-1 (reduction in $b^{*}$ from 8.09 in September to 4.69 in January). Thus, if using the commercial feed FT-1 and not applying water exchange, fish farmers should harvest the fish in January to ensure the least yellow flesh.

After slaughter, the yellow coloring of catfish flesh can also be minimized by chemical treatment, typically by dipping in sulfite solutions, as shown for channel catfish by Li et al. (2013, 2017). These authors found that the frequently observed yellow discoloration during refrigerated storage (assumed to originate from carotenoids or their degradation products) was reduced by the chemical treatment. However, from a consumer viewpoint, use of low-carotenoid feeds appears a more attractive approach than post-harvest treatment with chemicals to reduce the yellow color in fish.

\section{Carotenoids and fish health}

The absence of carotenoids in fish feed may have negative consequences to the health of the fish. Carotenoids are lipid-soluble compounds known to stimulate the immune defense and quench reactive oxygen species (Babin et al., 2015; Yujing et al., 2012). Supporting this, in yellow catfish (Pelteobagrus fulvidraco), supplementation of carotenoids to the feed has recently been shown to enhance the immune system by raising the lysozyme activity and the immuno-globulin level, and to reduce symptoms from high temperature stress (Liu et al., 2019). A similar immune stimulation was observed in the cold-water species rainbow trout (Oncorhynchus mykiss) when fed carotenoids from the marine alga Dunaliella (Amar et al., 2004). It remains to be determined if and how the present low-carotenoid feeds may affect fish health. During our study, no adverse effects on fish health from the absence of carotenoids were observed.

Irrespective of the positive or negative effects of carotenoids, maize and mustard cake will probably remain the preferred ingredients by the feed industry and by farmers who produce their own feed, since they are inexpensive sources of protein and carbohydrates, e.g., relative to soybean. Removal of carotenoids from maize might be a future option for feed production. Technically, carotenoids can be extracted from maize by combined supercritical fluid extraction and activated carbon treatment (Sessa et al., 2003) or by solvent extraction (Park et al., 1997). Presently, these techniques are expensive and not suited for large-scale production of maize for animal feeds.

\section{Phytoplankton as a source of carotenoids}

Pangasius is an omnivore species that may feed on algae (depending on the size of the algae) and detritus in the ponds as a supplement to added feed (The Fish Site, 2019). These additional food sources might also contribute carotenoids to farmed fish. In our study, abundance and composition of phytoplankton were monitored and showed that green algae made up the most abundant group of phytoplankton (Islam et al.; in preparation). Common pigments in green algae are lutein, $\beta$-carotene, violaxanthin, neoxanthin and zeaxanthin (Roy et al., 2011). Thus, ingestion of green algae in the ponds might have contributed carotenoids to the fish and added yellow color to the flesh.

In this study, the detection of carotenoids in pangasius that were fed the experimental feeds with a very low carotenoid content 
(below $1 \mathrm{mg} / \mathrm{kg}$ ) supports the view that the fish had an additional source of pigments, being phytoplankton or detritus in the ponds, but we cannot quantify this. Pigments extracted from phytoplankton are commonly used in feeds for color enrichment in fish (Shahidi et al., 1998), but it remains to be determined to which extent pigmentation of fish flesh is due to digestion of phytoplankton in aquaculture ponds.

\section{CONCLUSION}

In conclusion, this study demonstrates that pangasius with minimum yellow color can be produced in earthen ponds with natural well water in Bangladesh. The change in flesh color requires the application of low-carotenoid feeds and the introduction of regular water exchange. Replacement of maize as a common feed component by other ingredients, e.g., soybean meal, fish meal or meat and bone meal, may raise the production costs of the fish, but it may open the way for export to new markets for the benefit of the Bangladeshi aquaculture industry.

Compliance With Ethical Standard: The present study was conducted in accordance with the Ethical Standard of Research Committee of Bangladesh Agricultural Research System (BAURES), Bangladesh Agricultural University, Mymensingh.

Conflict of Interest : The authors declare that they have no conflicts of interest.

Financial Disclosure: This study project was funded by DANIDA (Denmark's development cooperation, Ministry of Foreign Affairs of Denmark) to the project "Upgrading pangas and tilapia value-chain in Bangladesh", Project Number F387-A26778

Acknowledgements: The authors would like to express sincere appreciation to Department of Plant and Environmental Sciences, University of Copenhagen; Department of Aquaculture, Patuakhali Science and Technology University; and Department of Aquaculture, Bangladesh Agricultural University for adequate field and laboratory facilities to complete this research successfully.

\section{REFERENCES}

Abedin, M.J., Abu, M., Bapary, J., Majumdar, B.C., Haque, M.M., Control, Q. (2017). Water quality parameters of some Pangasius ponds at Trishal Upazila, Mymensingh, Bangladesh. European Journal of Biotechnology and Bioscience, 5, 29-35. www.biosciencejournals. com; ISSN: 2321-9122

Alam, M.M., Haque, M.M., Aziz, M.S. Bin, Mondol, M.M.R. (2019). Development of pangasius-carp polyculture in Bangladesh: Understanding farm characteristics by, and association between, socio-economic and biological variables. Aquaculture, 505, 431-440. [CrossRef]

Ali, H., Haque, M.M., Belton, B. (2013). Striped catfish (Pangasianodon hypophthalmus, Sauvage, 1878) aquaculture in Bangladesh: An overview. Aquaculture Research, 44, 950-965. [CrossRef]

Amar, E.C., Kiron, V., Satoh, S., Watanabe, T. (2004). Enhancement of innate immunity in rainbow trout (Oncorhynchus mykiss Walbaum) associated with dietary intake of carotenoids from natural products. Fish \& Shellfish Immunology, 16, 527-537. [CrossRef]

Amaya, E., Nickell, D. (2015). Using feed to enhance the color quality of fish and crustaceans. In D.A. Davis (Ed.), Feed and Feeding Practices in Aquaculture. (pp. 269-298). Woodhead Publishing Series in Food Science, Technology and Nutrition. Amsterdam: Elsevier. [CrossRef]

Aruna, G., Baskaran, V. (2010). Comparative study on the levels of carotenoids lutein, zeaxanthin and $\beta$-carotene in Indian spices of nutritional and medicinal importance. Food Chemistry, 123, 404-409 [CrossRef]

Babin, A., Saciat, C., Teixeira, M., Troussard, J.P., Motreuil, S., Moreau, J., Moret, Y. (2015). Limiting immunopathology: Interaction between carotenoids and enzymatic antioxidant defences. Development \& Comparative Immunology, 49, 278-281. [CrossRef]

Belton, B., Haque, M.M., Little, D.C., Sinh, L.X. (2011). Certifying catfish in Vietnam and Bangladesh: Who will make the grade and will it matter? Food Policy, 36, 289-299. [CrossRef]

Blainey, P., Krzywinski, M., Altman, N., 2014. Replication. Natural Methods, 11, 879-880. [CrossRef]

de Carvalho, C.C.C.R., Caramujo, M.J. (2017). Carotenoids in aquatic ecosystems and aquaculture: A colorful business with implications for human health. Frontiers in Marine Science, 4, 93. [CrossRef]

DoF (2018). Yearbook of Fisheries Statistics of Bangladesh 2017-18. Fisheries resources survey system (FRSS), Department of Fisheries. Bangladesh: Ministry of Fisheries, 35, 129. www.fisheries.gov.bd

FAO (2018). http://www.fao.org/documents/card/en/c/l9540EN/ - The State of World Fisheries and Aquaculture 2018 - Meeting the sustainable development goals.

FAO (2019). http://www.fao.org/fishery/culturedspecies/Pangasius_ hypophthalmus/en\#tcNA0112

Gouveia, L., Rema, P., Pereira, O., Empis, J. (2003). Colouring ornamental fish (Cyprinus carpio and Carassius auratus) with microalgal biomass. Aquaculture Nutrition, 9, 123-129. [CrossRef]

Hoque, M.S., Haque, M.M., Hossain, M.I., Mahmud, S., Mandal, A.K., Badiuzzaman, Frederiksen, M., Larsen, E.P., Nielsen, M. (2021). Yellow fillets of Pangasius in Bangladesh: Prospects and challenges in international market.

Hu, B., Roy, L.A., Davis, D.A. (2013). Correlations of xanthophylls in catfish fillets, plankton, shad and snails in catfish production ponds in west Alabama. Aquaculture, 402-403, 46-49. [CrossRef]

Jespersen, K.S., Kelling, I., Ponte, S., Kruijssen, F. (2014). What shapes food value chains? Lessons from aquaculture in Asia. Food Policy, 49: 228-240. [CrossRef]

Kim, J.K., Lee, S.Y., Chu, S.M., Lim, S.H., Suh, S.-C., Lee, Y.-T., Cho, H.S., Ha, S.-H. (2010). Variation and correlation analysis of flavonoids and carotenoids in Korean pigmented rice (Oryza sativa L.) cultivars. Journal of Agricultural and Food Chemistry, 58, 12804-12809. [CrossRef]

Lee, P.H. (1987). Carotenoids in cultured channel catfish, 1987, PhD Dissertation. Auburn University, Alabama, USA, 84 pp.

Li, M.H., Robinson, E.H., Oberle, D.F., Lucas, P.M., Peterson, B.C., Bates, T.D. (2011). Clearance of yellow pigments lutein and zeathanxin in channel catfish, Ictalurus punctatus, reared at different water temperatures. Journal of the World Aquaculture Society, 42, 105110. [CrossRef]

Li, M.H., Robinson, E.H., Oberle, D.F., Zimba, P. V. (2007). Effects of various dietary carotenoid pigments on fillet appearance and pigment absorption in channel catfish, Ictalurus punctatus. Journal of the World Aquaculture Society, 38, 557-563. [CrossRef]

Li, Y., Liu, S., Cline, D., Chen, S., Wang, Y., Bell, L.N. (2013). Chemical treatments for reducing the yellow discoloration of channel catfish (Ictalurus punctatus) fillets. Journal of Food Science, 78, 1609-1613. [CrossRef]

Li, Y., Wang, Y., Boyd, C.E., Hanson, T.R., Liu, S. (2017). Evaluation and optimization of chemical treatments for reducing yellow discoloration of channel catfish (Ictalurus punctatus) fillets during cold storage. Journal of Aquatic Food Product Technology, 26, 132-137. [CrossRef] 
Liu, F., Qu, Y.K., Wang, A.M., Yu, Y.B., Yang, W.P., Lv, F., Nie, Q. (2019). Effects of carotenoids on the growth performance, biochemical parameters, immune responses and disease resistance of yellow catfish (Pelteobagrus fulvidraco) under high-temperature stress. Aquaculture, 503, 293-303. [CrossRef]

Liu, S., Li, Y., Wu, Y., Bell, L.N., Davis, D., Wang, Y. (2012). Extraction, identification and quantitation of carotenoids in discolored channel catfish (Ictalurus punctatus) fillets. Journal of Food Composition and Analysis, 26, 154-159. [CrossRef]

Lovell, T. (1998). Nutrition and feeding of fish, $2^{\text {nd }}$ ed. Boston: Kluwer Academic Publishers. [CrossRef]

Lovell, T. (1984). The yellow fat problem in fish flesh. Aquaculture Magazine, 10, 39-40

Lushchak, V.I., Bagnyukova, T. V. (2006). Effects of different environmental oxygen levels on free radical processes in fish. Comparative Biochemistry and Physiology Part B: Biochemistry and Molecular Biology, 144, 283-289. [CrossRef]

Maoka, T., Yokoi, S., Matsuno, T. (1989). Comparative biochemical studies of carotenoids in nine species of cephalopoda. Comparative Biochemistry and Physiology Part B: Comparative Biochemistry, 92, 247-250. [CrossRef]

The Fish Site (2019). Pangasius For Western Aquaculture | The Fish Site: https://thefishsite.com/articles/pangasius-for-western-aquaculture

Park, H., Flores, R.A., Johnson, L.A. (1997). Preparation of Fish Feed Ingredients: Reduction of carotenoids in corn gluten meal. Journal of Agricultural and Food Chemistry, 45, 2088-2092. [CrossRef]

Phan, L.T., Bui, T.M., Nguyen, T.T.T., Gooley, G.J., Ingram, B.A., Nguyen, H. V., Nguyen, P.T., De Silva, S.S. (2009). Current status of farming practices of striped catfish, Pangasianodon hypophthalmus in the Mekong Delta, Vietnam. Aquaculture, 296, 227-236. [CrossRef]

Qiufen, D., Yong, Y., Shi, S. (2012). Nutrition and changes in fish body colouration in catfish. AQUA Culture Asia Pacific Magazine, January/ February, 26-28

Roy, S., Llewellyn, C., Egeland, E.S., and Johnsen, G. (2011). Phytoplankton pigments: Characterization, chemotaxonomy and applications in oceanography. Cambridge: Cambridge University Press, UK, 845 pp [CrossRef]

Schlüter, L., Behl, S., Striebel, M., Stibor, H. (2016). Comparing microscopic counts and pigment analyses in 46 phytoplankton communities from lakes of different trophic state. Freshwater Biology, 61, 1627-1639. [CrossRef]

Sessa, D.J., Eller, F.J., Palmquist, D.E., Lawton, J.W. (2003). Improved methods for decolorizing corn zein. Industrial Crops and Products, 18, 55-65. [CrossRef]
Shahidi, F., Metusalach, Brown, J.A. (1998). Carotenoid pigments in seafoods and aquaculture. Critical Reviews in Food Science and Nutrition, 38, 1-67. [CrossRef]

Sheehan, E.M., O'Connor, T.P., Sheehy, P.J.A., Buckley, D.J., FitzGerald, R. (1998). Stability of astaxanthin and canthaxanthin in raw and smoked Atlantic salmon (Salmo salar) during frozen storage. Food Chemistry, 63, 313-317. [CrossRef]

Snodderly, D.M. (1995). Evidence for protection against age-related macular degeneration by carotenoids and antioxidant vitamins. American Journal of Clinical Nutrition, 62, 1448-1461. [CrossRef]

Trono, D., (2019). Carotenoids in cereal food crops: Composition and retention throughout grain storage and food processing. Plants, 8 , 551; [CrossRef]

Uddin, M.T., Rasel, M.H., Dhar, A.R., Badiuzzaman, M., Hoque, M.S. (2019). Factors determining consumer preferences for pangas and tilapia fish in Bangladesh: Consumers' perception and consumption habit perspective. Journal of Aquatic Food Product Technology, 28, 438-449. [CrossRef]

Van Heukelem, L., Thomas, C.S. (2001). Computer-assisted highperformance liquid chromatography method development with applications to the isolation and analysis of phytoplankton pigments. Journal of Chromatography A, 910, 31-49. [CrossRef]

Wathne, E., Bjerkeng, B., Storebakken, T., Vassvik, V., Odland, A.B. (1998). Pigmentation of Atlantic salmon (Salmo salar) fed astaxanthin in all meals or in alternating meals. Aquaculture, 159, 217-231. [CrossRef]

Waycott, B. (2015). Pangasius Farming: An overview. https://thefishsite. com/articles/pangasius-farming-an-overview.

Wu, T., Yao, Y., Sun, S., Wang, C., Jia, H., Man, W., Fu, L., Song, W., Wu, C., Jiang, B., Hou, W., Ren, G., Han, T., (2016). Temporospatial characterization of nutritional and bioactive components of soybean cultivars in China. Journal of the American Oil Chemists'Society, 93, 1637-1654; [CrossRef]

Young, A.J., Lowe, G.M. (2001). Antioxidant and prooxidant properties of carotenoids. Archives of Biochemistry and Biophysics, 385, 20-27. [CrossRef]

Yujing, S., Liping, Q., Liezhou, Z., Xingqian, Y. (2012). Recent advances of carotenoids bioactivities. Journal of Chinese Institute of Food Science and Technology, 12, 160-166.

Zimba, P. V., Mischke, C.C., Brashear, S.S. (2003). Pond age - Water column trophic relationships in channel catfish Ictalurus punctatus production ponds. Aquaculture 219, 291-301. [CrossRef] 